\title{
Effects of Alloy Elements on Oxidation Resistance and Stress-Rupture Property of P92 Steel
}

\author{
Gang Liu $\cdot$ Yu-Lai Xu $\cdot$ Cai-Xiong Yang $\cdot$ Xue-Shan Xiao $\cdot$ Xi-Min Chen $\cdot$ Xiao-Ke Zhang $\cdot$ Xiang-Jun Meng
}

Received: 16 May 2014/Revised: 7 July 2014/Published online: 15 November 2014

(C) The Chinese Society for Metals and Springer-Verlag Berlin Heidelberg 2014

\begin{abstract}
Effects of alloy elements $\mathrm{Cr}, \mathrm{W}, \mathrm{Ce}$, and $\mathrm{Si}$ on oxidation behavior at $750{ }^{\circ} \mathrm{C}$ in air and stress-rupture properties of $\mathrm{P} 92$ steel have been investigated. The proper increase in elements $\mathrm{Cr}, \mathrm{W}$, and $\mathrm{Ce}$ improved to varying degrees both oxidation resistance by either facilitating more protective $\mathrm{Cr}_{2} \mathrm{O}_{3}$ or modifying surface morphologies and stress-rupture life largely attributed to the formation of fine Laves phase. The excessive addition of Si significantly improved oxidation resistance of P92 steel, but dramatically impaired the stress-rupture life due to the formation and coarsening of Laves phase. The results indicate that proper additions of $\mathrm{Cr}, \mathrm{W}$, and $\mathrm{Ce}$ are beneficial for the comprehensive property of $\mathrm{P} 92$ steel.
\end{abstract}

KEY WORDS: P92; Oxidation resistance; Stress-rupture property; Microstructure

\section{Introduction}

Due to the excellent high-temperature mechanical properties, workability, and corrosion resistance property, the 9 wt\% Cr-contained ferritic steels such as P91 and P92 have been widely used for thick section boiler components, steam lines, turbine rotors, and turbine casings in steam power plant $[1,2]$. Oxidation has been observed as a predominant corrosion phenomenon of the ferritic steels exposed to environments from high temperature vapor or steam to supercritical water [3]. The oxide film with a typical duallayered structure, i.e., a Fe-rich outer layer and a $\mathrm{Cr} / \mathrm{Fe}$-rich inner layer, formed on the steels after long-term oxidation [4-6]. Exposure temperature and time exert significant

Available online at http://link.springer.com/journal/40195

G. Liu · Y.-L. Xu · C.-X. Yang · X.-S. Xiao (ه)

Laboratory for Microstructures, Institute of Materials, Shanghai

University, Shanghai 200072, China

e-mail: xsxiao@mail.shu.edu.cn

X.-M. Chen · X.-K. Zhang · X.-J. Meng

Baosteel Special Materials Co., Ltd, Shanghai 200940, China effects on surface morphologies, oxide scale thickness, and oxide constituents. Besides, alloying elements also have important influence on the oxidation resistance of the ferritic steels. Chromium is the first of all elements utilized for the high temperature corrosion of the steels, and generally the higher the chromium concentration, the higher the oxidation resistance the steel will be. For example, Wright and Pint [7] reported that HCM12A showed a higher oxidation resistance than that of NF616 under steam atmosphere due to the higher $\mathrm{Cr}$ content. Furthermore, small amounts of additional alloying elements, such as $\mathrm{Mn}, \mathrm{Mo}$, and $\mathrm{Si}$, have a significant influence on oxidation behavior. As the most element, $\mathrm{Si}$ is well known for its positive influence on oxidation in general. Sometimes the oxidation resistance of the steels was improved in the Si-added steel because of the formation of $\mathrm{SiO}_{2}$ oxidation particles $[8,9]$. The oxidation resistance can also be improved by covering a Ce film on the surface of the steels [10]. In another case, Si seemed to benefit oxidation resistance of $9 \mathrm{wt} \% \mathrm{Cr}$ steels in water vapor-containing environment with regards to retarding breakaway oxidation and may even help with the repassivation effect after breakaway during long-term oxidation [11]. In fact, the main alloy elements (Cr, Si, Mn, Mo, and $\mathrm{W}$ ) have not only a 
specific influence but also a joint influence on the corrosion behavior of the $9-13$ wt\% Cr ferritic steels and cannot be considered separately [12].

Modified on the basis of P91, P92 steel shows improved high-temperature mechanical properties, especially a $10-20 \%$ increase in creep strength at $600{ }^{\circ} \mathrm{C}$ for $10,000 \mathrm{~h}$ due to solution strengthening by $\mathrm{W}$ and Mo, and precipitation strengthening by $\mathrm{V}$ and $\mathrm{Nb}$ additions [13]. It is also widely accepted that the method of micro-alloying is worth researching in terms of improving the high-temperature mechanical properties of steels. $\mathrm{W}$, as a refractory element, is usually supposed to keep steels' stability at elevated temperature mainly by constituting second-phase particles. Rare earth elements such as Ce also draw attention in modifying steels for its strong segregation at grain boundary and modification of inclusions [14]. It is widely known that the excellent comprehensive performance of $9 \mathrm{wt} \% \mathrm{Cr}-$ contained ferritic steels is primarily attributed to the tempered martensitic lath structure (TMLS) which is stabilized by a dispersion of nanoscale particles [15]. Among those particles are $\mathrm{M}_{23} \mathrm{C}_{6}$ and $\mathrm{MX}$ carbonitrides, and the $\mathrm{MX}$ is usually considered to be of more importance to improve creep strength of the steels for its high stability during aging and creep tests [16-18]. Ma et al. [19] reported that the addition of $\mathrm{V}, \mathrm{Ti}$, and $\mathrm{B}$ in $9 \mathrm{Cr}$ low activation martensitic steel accelerated the formation of MX precipitates and resulted in fine grains and precipitates. Laves phase precipitating in $9 \mathrm{wt} \% \mathrm{Cr}$-contained ferritic steels after longterm thermal aging or creep exposure also have significant influence on mechanical properties, which mainly depends on its size and distribution. Laves phase with small size favors the creep strength of the steels, while the Laves phase with large size can impair the creep property [20,21].

In this paper, by adding alloying elements $\mathrm{Cr}, \mathrm{W}, \mathrm{Ce}$, and Si respectively or collaboratively into $\mathrm{P} 92$, the effects of these alloying elements on oxidation behavior at $750{ }^{\circ} \mathrm{C}$ in air and high-temperature mechanical properties of $\mathrm{P} 92$ steel have been investigated.

\section{Experimental}

The steels were melted in a $50 \mathrm{~kW}$ induction furnace in an argon atmosphere and the casting ingots with a diameter of
$120 \mathrm{~mm}$ were hot forged into sticks of $40 \mathrm{~mm}$ in diameter. The chemical compositions of the cast steels are shown in Table 1. The base sample and modified steels of P92 with additional alloying elements $\mathrm{Cr} / \mathrm{W}, \mathrm{Ce}$, and $\mathrm{Ce} / \mathrm{Si}$ are designated as the Nos.1-4 steels, respectively. After forging, all the steels were normalization heat treated at $1,060{ }^{\circ} \mathrm{C}$ for $20 \mathrm{~min}$ followed by air cooling (AC) and subsequently tempered at $765{ }^{\circ} \mathrm{C}$ for $3 \mathrm{~h}$ followed by AC. After normalization and tempering, the specimens of approximately $30 \times 10 \times 2 \mathrm{~mm}$ were cut from the sheets. Isothermal oxidation tests were conducted at $750{ }^{\circ} \mathrm{C}$ in air with the oxidation time ranging from $100 \mathrm{~h}$ to $700 \mathrm{~h}$. The specimens were ground with abrasive papers and polished with the $1.0 \mu \mathrm{m}$ diamond paste before placing in the tube furnace. The mass of each specimen before and after oxidation was measured using Sartorius BP211D microbalance with a resolution of $10^{-5} \mathrm{~g}$. HITACHI SU-1510 SEM equipped with EDS was used to investigate the morphologies and chemical compositions of the oxidation films formed on the specimens. The samples obtained from the isothermal oxidation tests for the cross-section investigation were mounted in epoxy resin and were prepared by grinding, polishing and chemical etching. Raman spectroscopy with resolution of $1 \mathrm{~cm}^{-1}$ was used to identify the phase constitution of the oxide films. The samples were illuminated by a $514.5 \mathrm{~nm}$ argon ion laser on a BHSM Olympus confocal microscope with the magnification factor of 1,000 .

After normalization and tempering, a portion of the samples was conducted aging heat treatment at $625^{\circ} \mathrm{C}$ for $1,000 \mathrm{~h}$ followed by AC, and these samples were further undertaken stress-rupture tests carried out first at $625^{\circ} \mathrm{C} /$ $125 \mathrm{MPa}$ for $2,900 \mathrm{~h}$ and at $625^{\circ} \mathrm{C} / 140 \mathrm{MPa}$ afterward. The specimens for the stress-rupture tests were prepared according to the National Standard of the PR China, GB/ T2039-1997. The samples were crept up to fracture, at least three samples were prepared for the stress-rupture tests, and the average value was taken as the stress-rupture life.

Microstructure of the specimens was analyzed by optical microscopy (OM), JSM-6700F scanning electron microscope (SEM) equipped with energy dispersive spectroscopy (EDS) and JEM-2010F transmission electron microscope (TEM). The samples for OM were prepared by grinding using $\mathrm{SiC}$ abrasive papers from No. 200 up to No.

Table 1 Chemical compositions (wt \%) of the steels

\begin{tabular}{llllllllllllll}
\hline Steel & $\mathrm{C}$ & $\mathrm{N}$ & $\mathrm{Ce}$ & $\mathrm{Mn}$ & $\mathrm{Si}$ & $\mathrm{Cr}$ & $\mathrm{W}$ & $\mathrm{Mo}$ & $\mathrm{V}$ & $\mathrm{Nb}$ & $\mathrm{Ni}$ & $\mathrm{Ti}$ & $\mathrm{Fe}$ \\
\hline No. 1 & 0.095 & 0.054 & - & 0.42 & 0.26 & 8.73 & 1.83 & 0.51 & 0.21 & 0.06 & 0.30 & 0.01 & Bal. \\
No. 2 & 0.103 & 0.049 & - & 0.42 & 0.28 & 9.38 & 1.97 & 0.48 & 0.21 & 0.06 & 0.29 & 0.01 & Bal. \\
No. 3 & 0.093 & 0.054 & 0.02 & 0.42 & 0.26 & 8.72 & 1.83 & 0.51 & 0.19 & 0.06 & 0.30 & 0.01 & Bal. \\
No. 4 & 0.093 & 0.052 & 0.02 & 0.41 & 0.78 & 8.71 & 1.83 & 0.50 & 0.21 & 0.06 & 0.30 & 0.01 & Bal. \\
\hline
\end{tabular}


1,000 , electrolytic polishing in a solution composed of $10 \mathrm{~mL} \mathrm{HClO}_{4}+90 \mathrm{~mL} \mathrm{CH} \mathrm{CH}_{3} \mathrm{COOH}$ at $25 \mathrm{~V}$ and then chemical etching in a solution composed of $5 \mathrm{~g}$ $\mathrm{FeCl}_{3}+20 \mathrm{~mL} \mathrm{HCl}+20 \mathrm{~mL} \mathrm{C}_{2} \mathrm{H}_{5} \mathrm{OH}$. The foils for TEM observation were prepared by hand grinding to a thickness of $60 \mu \mathrm{m}$, and then thinned using a twin-jet electro-polishing in the solution composed of $10 \% \mathrm{HClO}_{4}$ and $90 \% \mathrm{C}_{2} \mathrm{H}_{5} \mathrm{OH}$ at $35 \mathrm{~V}$ and $-30{ }^{\circ} \mathrm{C}$.

\section{Results and Discussion}

\subsection{Oxidation Resistance}

Figure 1 shows the isothermal oxidation kinetic curves of the specimens at $750{ }^{\circ} \mathrm{C}$ in air with the oxidation time ranging from $100 \mathrm{~h}$ to $700 \mathrm{~h}$. The corrosion weight of No. 2 and No. 3 steels increased slightly compared with that of No. 1 steel during the first $100 \mathrm{~h}$ and then increased gradually after oxidized over $100 \mathrm{~h}$ with the oxidation kinetic curve presenting a parabolic regime, indicating that the oxidation resistance of P92 steel was improved slightly by $\mathrm{Ce}$ addition and pronouncedly by both $\mathrm{Cr}$ and $\mathrm{W}$ additions. After adding Si into P92 steel, the oxidation resistance was dramatically improved and the corrosion weight hardly increased after oxidation at $750{ }^{\circ} \mathrm{C}$ for $700 \mathrm{~h}$ in air.

The surface morphologies of oxide scales of the steels after oxidation at $750{ }^{\circ} \mathrm{C}$ for $700 \mathrm{~h}$ in air are presented in Fig. 2. For No. 2 and No. 3 steels, few pores on the scale surfaces were observed as compared with that of No. 1 steel. In particular, the dense-distributed granular oxide identified on the surface of No. 3 steel makes the scale more compact than that of the base steel. For Fe-Cr alloys,

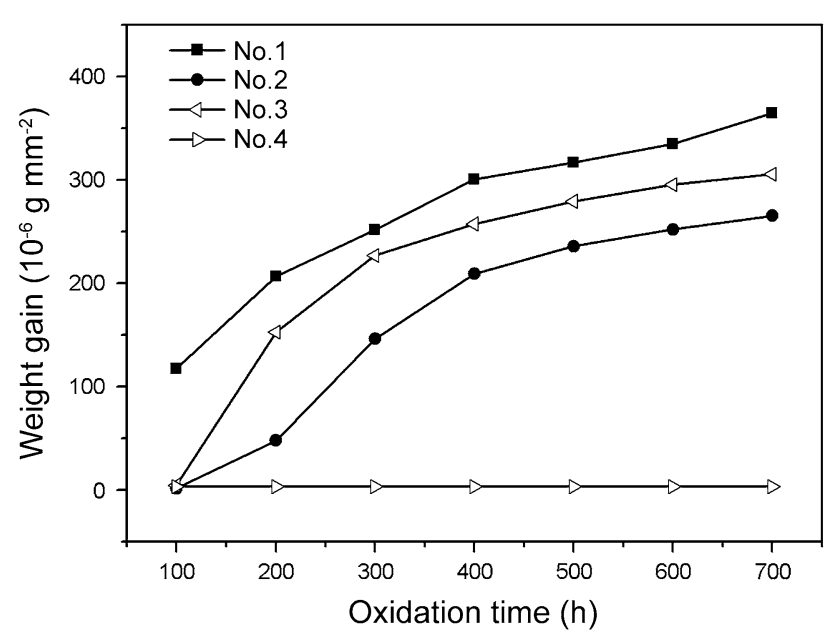

Fig. 1 Oxidation kinetic curves of Nos. 1-4 steels at $750{ }^{\circ} \mathrm{C}$ for $700 \mathrm{~h}$ in air the continuous growth of the oxide scale during the exposure time requires the outwards migration of Fe cations and the inwards diffusion of the oxygen ions, which is probably affected by short-circuit paths such as pores, cracks, and grain boundaries [4]. The decrease of the pores in oxide scale of No. 2 and No. 3 steels may hinder the diffusion of cations and ions and results in the enhanced oxidation resistance as confirmed by Fig. 1. More compact granular oxide in No. 4 steel compared with that of No. 3 was also revealed by the surface morphology, which indicates a higher oxidation resistance of No. 4 steel.

The cross-section morphologies of the steels after oxidation at $750{ }^{\circ} \mathrm{C}$ for $700 \mathrm{~h}$ in air are shown in Fig. 3. A collection of various reference oxide spectra of iron and chromium is presented in Table 2 with the strongest modes underlined [22, 23]. As shown in Fig. 3, approximately three oxidation layers are formed for Nos. 1-3 steels after oxidation at $750{ }^{\circ} \mathrm{C}$ for $700 \mathrm{~h}$ in air. The corresponding SEM-EDSs show that the inner and intermediate layers are rich in $\mathrm{Cr}$ and $\mathrm{Fe}$, while the outer layer is only rich in Fe. Figures 4 and 5 show the Raman spectra of tested samples obtained by spotting a laser beam on different regions of the oxide film corresponding the numbers marked in Fig. 3. The spectrum of region 1 reveals two peaks located at $\sim 550$ and $680 \mathrm{~cm}^{-1}$, which are characteristic of $\mathrm{Cr}_{2} \mathrm{O}_{3}$ and $\mathrm{Fe}_{3} \mathrm{O}_{4}$, respectively. The phase constitution of region 1 therefore can be identified to be $\mathrm{Cr}_{2} \mathrm{O}_{3}$ and $(\mathrm{Fe}, \mathrm{Cr})_{3} \mathrm{O}_{4}$ with the combination of SEM-EDSs and Raman analysis. The spectrum of region 2 shows two obvious peaks at $\sim 560,680 \mathrm{~cm}^{-1}$ and a weak peak at $\sim 320 \mathrm{~cm}^{-1}$, which are responsible for $\mathrm{Fe}_{3} \mathrm{O}_{4}$. So the phase constitution of region 2 is recognized as $(\mathrm{Fe}, \mathrm{Cr})_{3} \mathrm{O}_{4}$ in the same way. The spectrum of region 3 significantly differs from those of region 1 and 2 with strong peaks located at $\sim 225,295$, $415,500 \mathrm{~cm}^{-1}$ and two weak peaks centered at $\sim 615$ and $680 \mathrm{~cm}^{-1}$. The peaks at $\sim 225,295,415,500$, and $615 \mathrm{~cm}^{-1}$ are assigned as $\alpha-\mathrm{Fe}_{2} \mathrm{O}_{3}$, while the peak at $\sim 680 \mathrm{~cm}^{-1}$ as $\mathrm{Fe}_{3} \mathrm{O}_{4}$. Hence, the phase constitutions of region 3 are identified as $\alpha-\mathrm{Fe}_{2} \mathrm{O}_{3}$ and $\mathrm{Fe}_{3} \mathrm{O}_{4}$.

This triplex layer of the oxide products of No. 1 steel after oxidation at $750{ }^{\circ} \mathrm{C}$ for $700 \mathrm{~h}$ in air is further verified by the EDS line-scans in Fig. 6, namely the innermost Fe/ Cr-rich $\mathrm{Cr}_{2} \mathrm{O}_{3}$ and $(\mathrm{Fe}, \mathrm{Cr})_{3} \mathrm{O}_{4}$ corresponding sector 1 , the intermediate $\mathrm{Fe} / \mathrm{Cr}$-rich $(\mathrm{Fe}, \mathrm{Cr})_{3} \mathrm{O}_{4}$ to sector 2, and the outermost Fe-rich $\alpha-\mathrm{Fe}_{2} \mathrm{O}_{3}$ and $\mathrm{Fe}_{3} \mathrm{O}_{4}$ to sector 3. These line-scans also reveal that there is an obvious different ratio of $\mathrm{Fe}$ and $\mathrm{Cr}$ in the two $\mathrm{Fe} / \mathrm{Cr}$-rich inner layers. The outwards diffusion of $\mathrm{Fe}$ cations results in the more iron-rich intermediate oxide layer and the innermost more chromium-rich thin layer along the scale/metal interface which have a good barrier effect [2]. Laverde et al. [4] suggested that three oxide layers constituted the oxide scales of T91 ferritic steel in steam within a temperature range between 

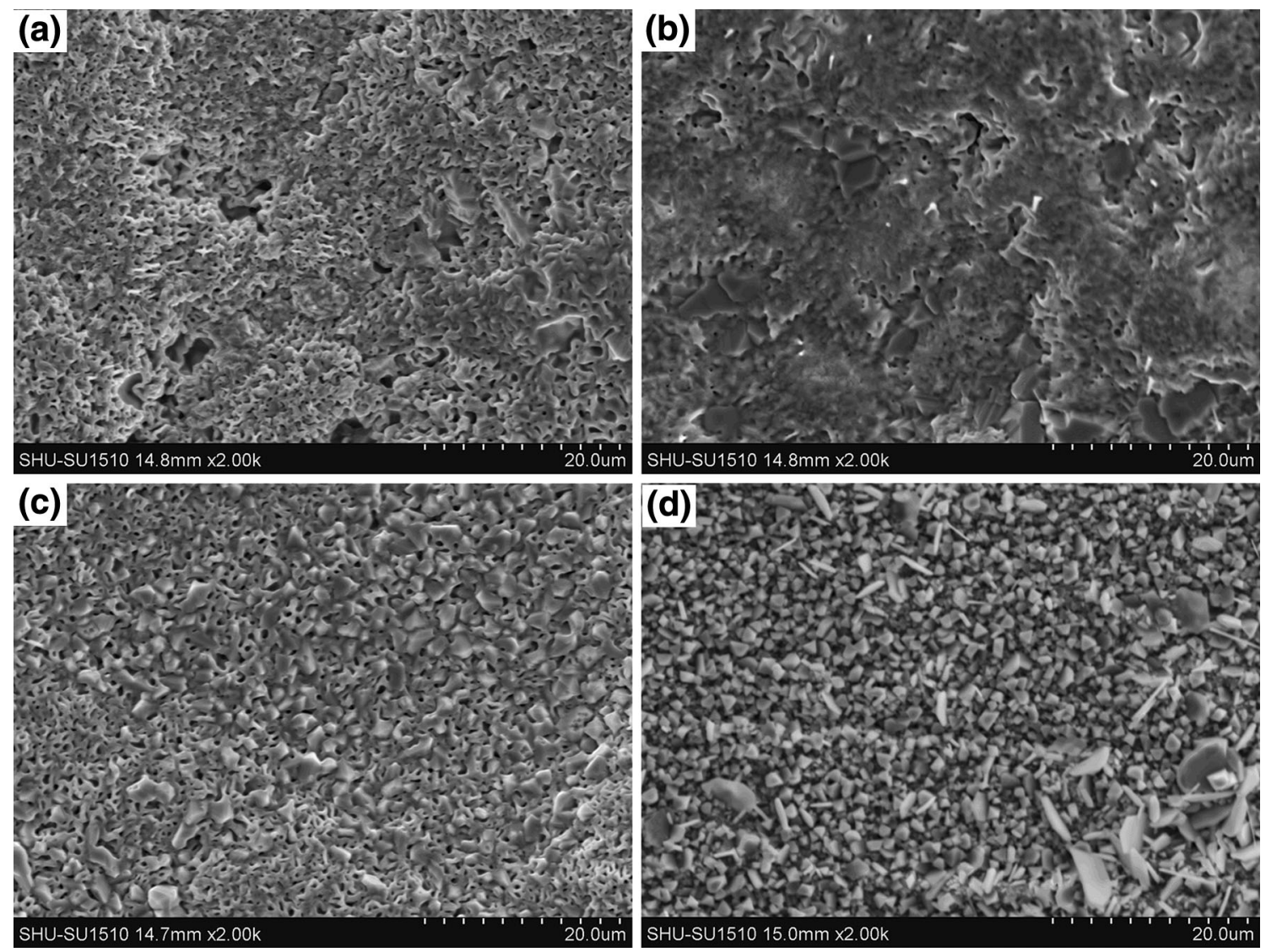

Fig. 2 The surface morphologies of oxide scales of No. 1 a, No. 2 b, No. 3 c, No. 4 d steels after oxidation at $750{ }^{\circ} \mathrm{C}$ for 700 h in air

575 and $700{ }^{\circ} \mathrm{C}$, i.e., the innermost $(\mathrm{Fe}, \mathrm{Cr})_{3} \mathrm{O}_{4}$ layer, the intermediate $\mathrm{Fe}_{3} \mathrm{O}_{4}$ layer, and the outer $\mathrm{Fe}_{2} \mathrm{O}_{3}$ layer. Yan et al. [13] also found that when P92 steel was exposed to supercritical water at $500-600{ }^{\circ} \mathrm{C}$ and $25 \mathrm{MPa}$, a duallayered oxide scale, which was mainly composed of an outer $\mathrm{Fe}_{3} \mathrm{O}_{4}$ layer and an inner $\mathrm{Fe}_{3} \mathrm{O}_{4} /(\mathrm{Fe}, \mathrm{Cr})_{3} \mathrm{O}_{4}$-mixed layer, formed on it. On the whole, the sequence of the oxide layers formed in the present work may therefore be considered as a common feature of oxidation behavior of chromium-containing steels. Due do relatively less water vapor content and lower oxygen partial pressure in exposure condition, only one Fe-rich layer was formed on the top of oxidation scales. The two inner $\mathrm{Cr} / \mathrm{Fe}$-rich layers, particularly the formation of $\mathrm{Cr}_{2} \mathrm{O}_{3}$, play an important role in the passivation process of the steel [7-10].

According to Raman spectra analysis shown in Figs. 4 and 5, the oxidation products of No. 2 and No. 3 steel with a small amount of $\mathrm{Cr}, \mathrm{W}$, or Ce did not changed obviously compared with those of No. 1 steel. However, the outer Ferich layer of No. 2 steel is somewhat thinner, and the inner $\mathrm{Cr} / \mathrm{Fe}$-rich layer is thicker than the counterparts of No. 1 steel, which is well understandable that a higher $\mathrm{Cr}$ content will increase the formation of protective chromium oxide and restrain the $\mathrm{Fe}$ to be oxidized, even though the $\mathrm{Cr}$ content does not increase obviously in the present work. Wright et al. [7] also reported that as to the double-layered scales of $\mathrm{Fe}-\mathrm{Cr}$ alloys oxidized in steam, the ratio of the thickness of the inner and outer layers was independent of time, but increased with increasing $\mathrm{Cr}$ content. In No. 3 steel added $\mathrm{Ce}$, the boundary of the $\mathrm{Fe} / \mathrm{Cr}$-rich inner layer and Fe-rich outer layer became vague, and the thickness of the outer oxidation layer was evidently smaller than that of No. 1 steel shown in Fig. 3. As a kind of reactive element, $\mathrm{Ce}$ may decrease the oxidation rate, accelerate the $\mathrm{Cr}_{2} \mathrm{O}_{3}$ growth, and retard the $\mathrm{Fe}$-oxides formation by decreasing the density of vacancy defects in oxidized layer so that the diffusion outward of cations through vacancies is restrained [24]. The oxidation behavior of No. 4 steel with both Ce and $\mathrm{Si}$ additions changed significantly. As shown in Fig. 3d, the thickness of the single oxidation layer is merely about $1.2 \mu \mathrm{m}$ after oxidation at $750{ }^{\circ} \mathrm{C}$ for $700 \mathrm{~h}$ in air. The corresponding SEM-EDSs show that it composed of large amount of $\mathrm{Cr}$ and small amount of Fe. The Raman spectra present two sharp peaks at $\sim 550$ and $680 \mathrm{~cm}^{-1}$, which are the characteristic of $\mathrm{Cr}_{2} \mathrm{O}_{3}$ and $\mathrm{Fe}_{3} \mathrm{O}_{4}$, respectively. Hence, the phase constitution of the oxidation layer in No. 4 steel is $\mathrm{Cr}_{2} \mathrm{O}_{3}$ and $(\mathrm{Fe}, \mathrm{Cr})_{3} \mathrm{O}_{4}$. Although the phase constitution of the oxidation products closed to the 

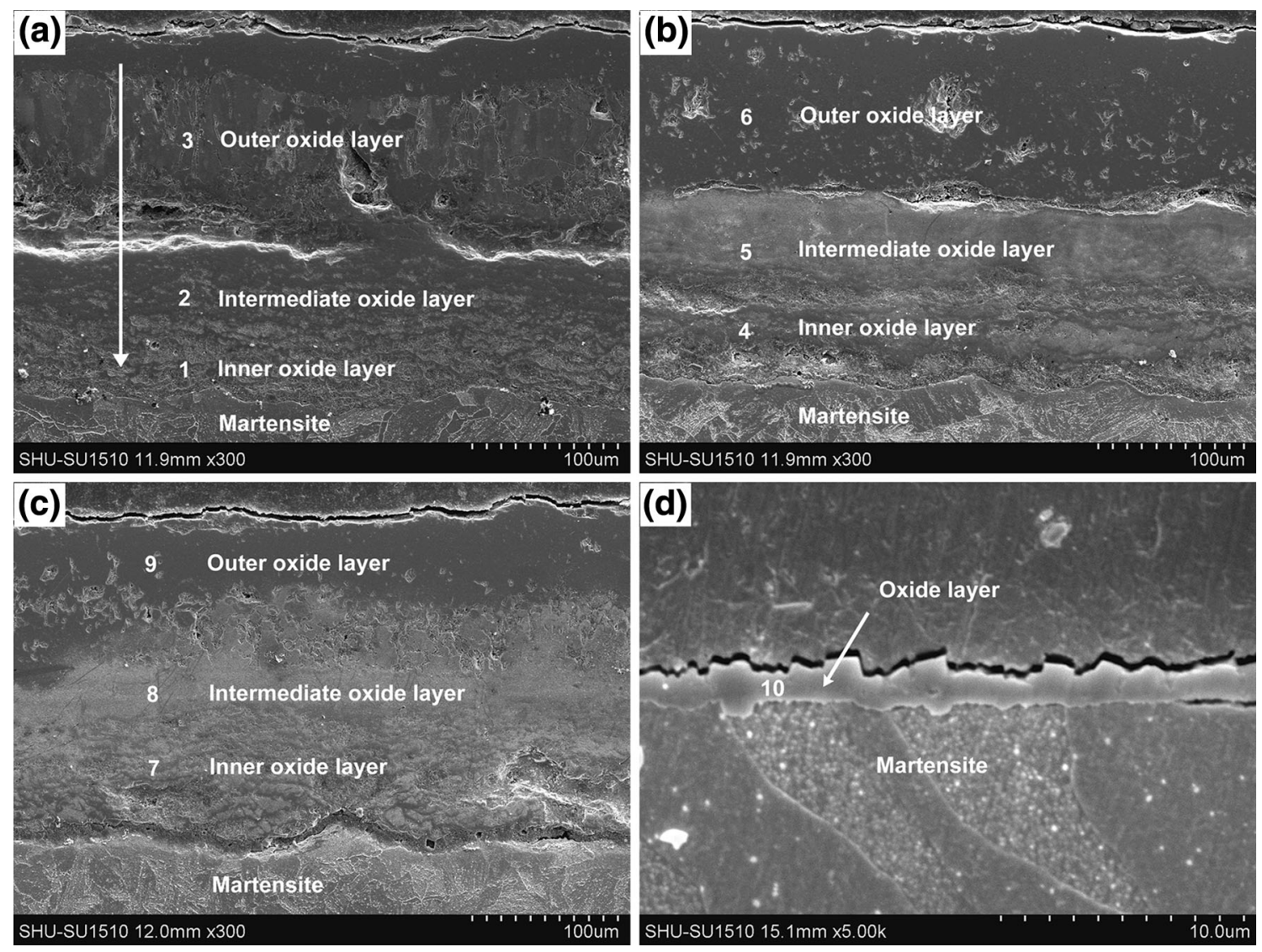

Fig. 3 The cross-section morphologies of No. 1 a, No. 2 b, No. $3 \mathbf{c}$, No. $4 \mathbf{d}$ steels after oxidation at $750{ }^{\circ} \mathrm{C}$ for 700 h in air. The arrow in No. 1 shows the EDS line-scans direction. The areas spotted by laser beam in Raman analysis are marked by numbers

Table 2 Locations $\left(\mathrm{cm}^{-1}\right)$ of Raman-active vibrational modes of oxides of iron and chromium

\begin{tabular}{|c|c|c|c|c|c|c|c|c|c|c|}
\hline \multirow{2}{*}{$\frac{\text { Species }}{\alpha-\mathrm{Fe}_{2} \mathrm{O}_{3}}$} & \multicolumn{10}{|c|}{ Peak $\left(\mathrm{cm}^{-1}\right)$} \\
\hline & 226 & 245 & 296 & & 411 & 495 & & 612 & & \\
\hline$\alpha-\mathrm{Fe}_{2} \mathrm{O}_{3}$ & $\underline{225}$ & 245 & $\underline{295}$ & & $\underline{415}$ & 500 & & 615 & & \\
\hline $\mathrm{Fe}_{3} \mathrm{O}_{4}$ & & & & & & & 550 & & & $\underline{670}$ \\
\hline $\mathrm{Fe}_{3} \mathrm{O}_{4}$ & & & 300 & 320 & 420 & & 560 & & & $\underline{680}$ \\
\hline $\mathrm{Cr}_{2} \mathrm{O}_{3}$ & & & $\underline{303}$ & & 351 & 397 & 530 & $\underline{550}$ & 609 & \\
\hline
\end{tabular}

The high-intensity modes are underlined

substrate in all the samples is the same, it should be noted that the peak at $\sim 550 \mathrm{~cm}^{-1}$ of the spectrum in No. 4 steel is much clearer and sharper than those in the inner oxide layer of other steels, indicating that a higher $\mathrm{Cr}_{2} \mathrm{O}_{3}$ content may be produced due to the $\mathrm{Si}$ addition in No. 4 steel.

Previous studies $[6,25,26]$ have reported that the increase of $\mathrm{Si}$ element could improve the oxidation resistance of $\mathrm{Cr}$-containing martensitic steels by facilitating the formation of a chromia scale on the surface of the steel. Huntz et al. [25] pointed out that when a kind of $9 \mathrm{wt} \% \mathrm{Cr}$ steels was doped with (2-4) wt\% $\mathrm{Si}$ and was oxidized at 600 and $950{ }^{\circ} \mathrm{C}$ in $\mathrm{Ar}$ which contained trace amount of $\mathrm{H}_{2}$ and $\mathrm{H}_{2} \mathrm{O}$, and continuous chromia was formed on the alloy surface underneath which thin silica films were also observed. It was proposed that this silica film pronouncedly decreased the oxygen activity so that $\mathrm{Fe}$-oxides were unstable, and this silica film acted as a diffusion barrier that $\mathrm{Cr}$ can go through to form the chromia layer while $\mathrm{Fe}$ is blocked. Meier et al. [26] agreed with this point when the oxidation resistance property of $\mathrm{Fe}-8 \mathrm{Cr}$ with $0.3 \mathrm{Si}$ was as good as $\mathrm{Fe}-16 \mathrm{Cr}$ binary alloys in $\mathrm{Ar}-50 \% \mathrm{H}_{2} \mathrm{O}$ at 550 and $650{ }^{\circ} \mathrm{C}$ that the silica formation lowers the oxygen partial pressure on the alloy surface and suppressed the Fe-oxide formation, even if only trace remnants of silica were found 


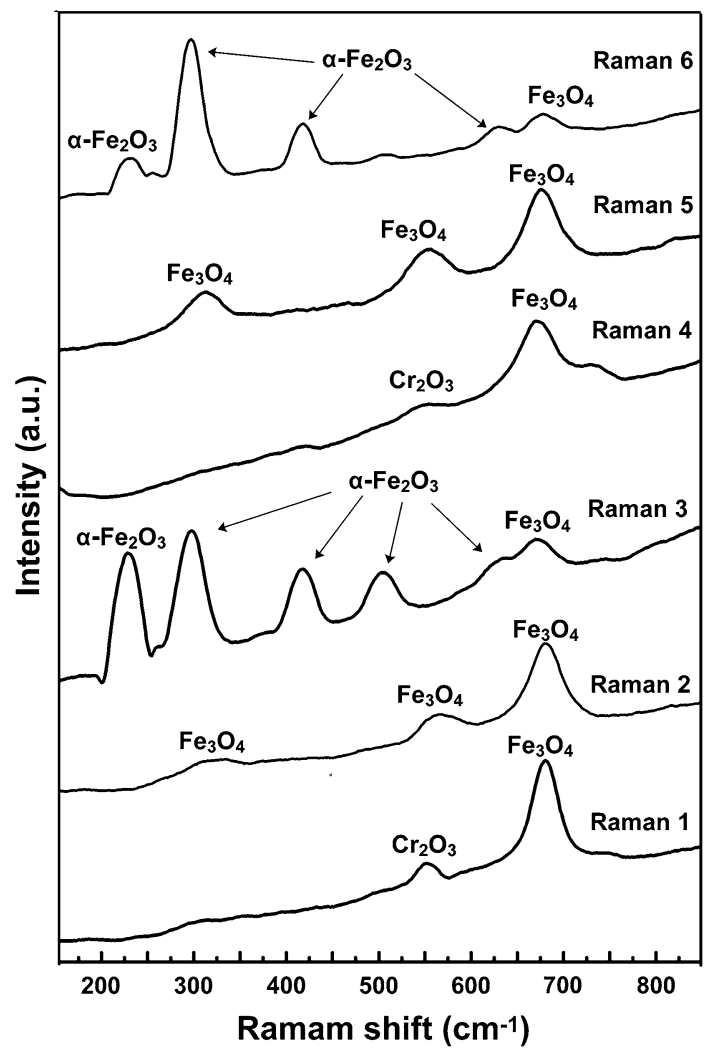

Fig. 4 Raman spectra of the cross-section of No. 1 and No. 2 specimens corresponding to the regions in Fig. $3 \mathbf{a}, \mathbf{b}$ after oxidation at $750{ }^{\circ} \mathrm{C}$ for $700 \mathrm{~h}$ in air

by the SNMS (Sputtered Neutrals Mass Spectroscopy) analyses in the outer part of the scale. It was also found in XPS (X-ray photoelectron spectroscopy) that Si enrichment occurs in the very early stage of oxidation, i.e., after very short exposure times of a few minutes or hours [25]. The amounts of $\mathrm{Si}$ are too small to be detected by XRD or EDS, as did in our case. This beneficial effect of $\mathrm{Si}$ in combination with the function of $\mathrm{Ce}$ that restrained vacancy defects discussed above leads to the extremely thin, as well as compact, oxidation scale (Fig. 3d). The dramatically improved oxidation resistance of No. 4 steel may be attributed to the possible synergistic effects of $\mathrm{Cr}$ and $\mathrm{Ce}$ alloying elements.

\subsection{Stress-Rupture Properties}

The microstructures of No. 1 steel after heat treatment at $1,060{ }^{\circ} \mathrm{C} \times 20 \mathrm{~min}, \mathrm{AC}+765^{\circ} \mathrm{C} \times 3 \mathrm{~h}$, AC are presented in Fig. 7. The typical tempered lath martensite morphology of No. 1 steel is shown in Fig. 7a, and the corresponding SEM-EDS in Fig. $7 \mathrm{~b}$ shows that $\mathrm{M}_{23} \mathrm{C}_{6}$ carbides rich in $\mathrm{Cr}, \mathrm{Fe}, \mathrm{W}, \mathrm{Mo}$, and $\mathrm{C}$ elements were found at the prior austenite grain boundaries and the interface of $\delta$-ferrite/martensite matrix. Except for the $\mathrm{M}_{23} \mathrm{C}_{6}$ carbides

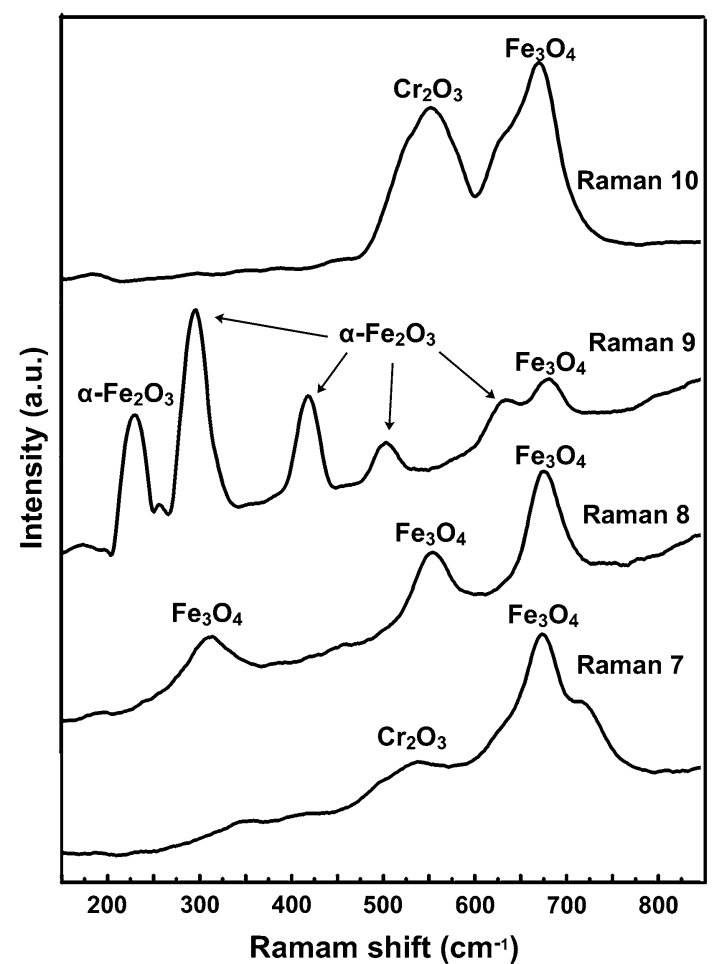

Fig. 5 Raman spectra of the cross-section of No. 3 and No. 4 specimens corresponding to the regions in Fig. $3 \mathbf{c}, \mathbf{d}$ after oxidation at $750{ }^{\circ} \mathrm{C}$ for $700 \mathrm{~h}$ in air

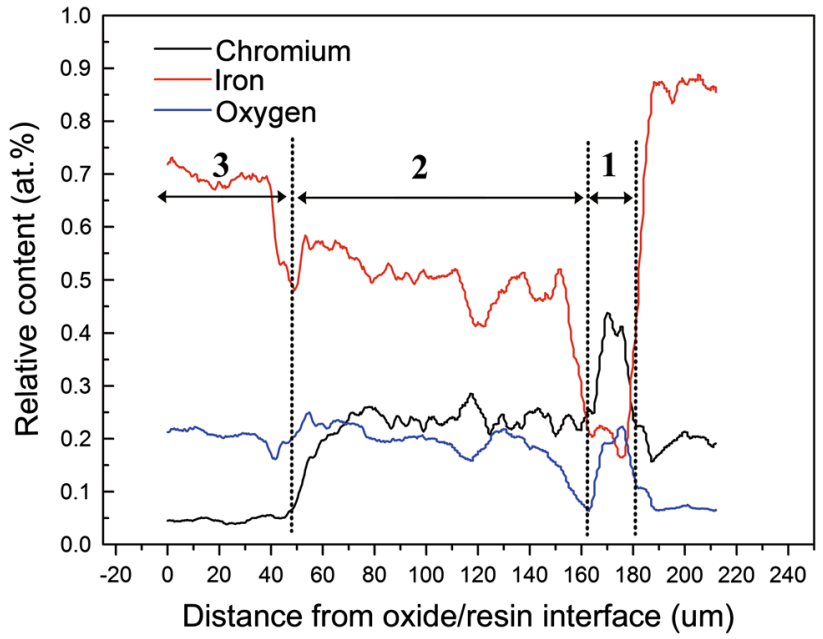

Fig. 6 EDS line-scans of cross-section of No. 1 steel after oxidation at $750{ }^{\circ} \mathrm{C}$ for $700 \mathrm{~h}$ in air with the scanning direction showing in Fig. 3a. The numbers correspond with those numbers in Fig. 3a

at the martensite lath boundary (Fig. 7c) and in the martensite lath interior (Fig. 7e), the TEM micrographs show that the MX carbonitrides are also identified in the martensite lath interior shown in Fig. 7d and e. Generally Nbrich MX with a spherical shape and V-rich MX with a plate-like shape appear to remain undissolved after 

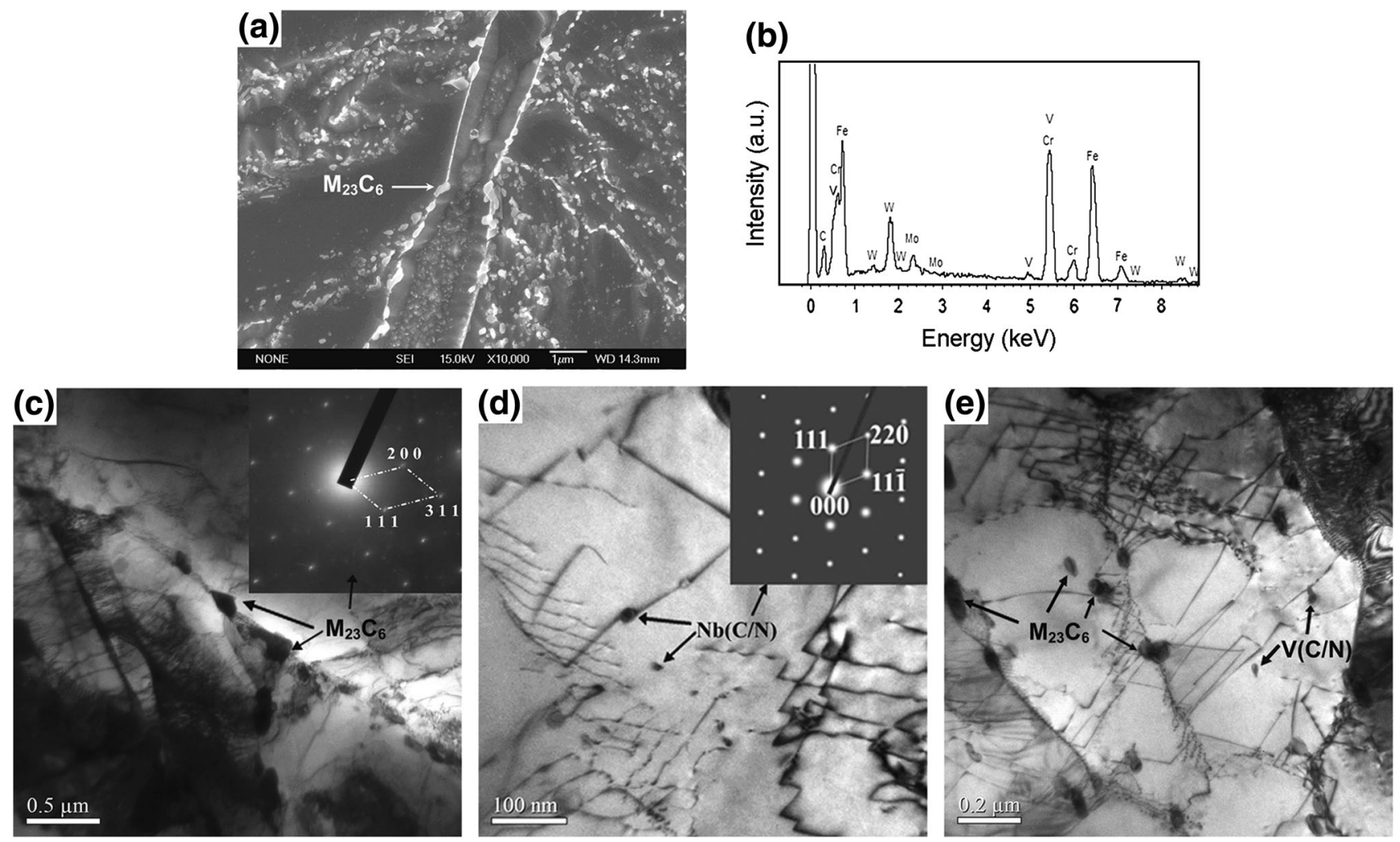

Fig. 7 Micrographs of No. 1 steel after heat treatment at $1,060{ }^{\circ} \mathrm{C} \times 20 \min \mathrm{AC}+765{ }^{\circ} \mathrm{C} \times 3 \mathrm{~h}$ AC: a SEM micrograph, $\mathbf{b}$ The SEM-EDS of particles in Fig. 7a; c, d, e TEM micrographs with diffraction patterns of $\mathrm{M}_{23} \mathrm{C}_{6}$ and $\mathrm{Nb}(\mathrm{C} / \mathrm{N})$ particles
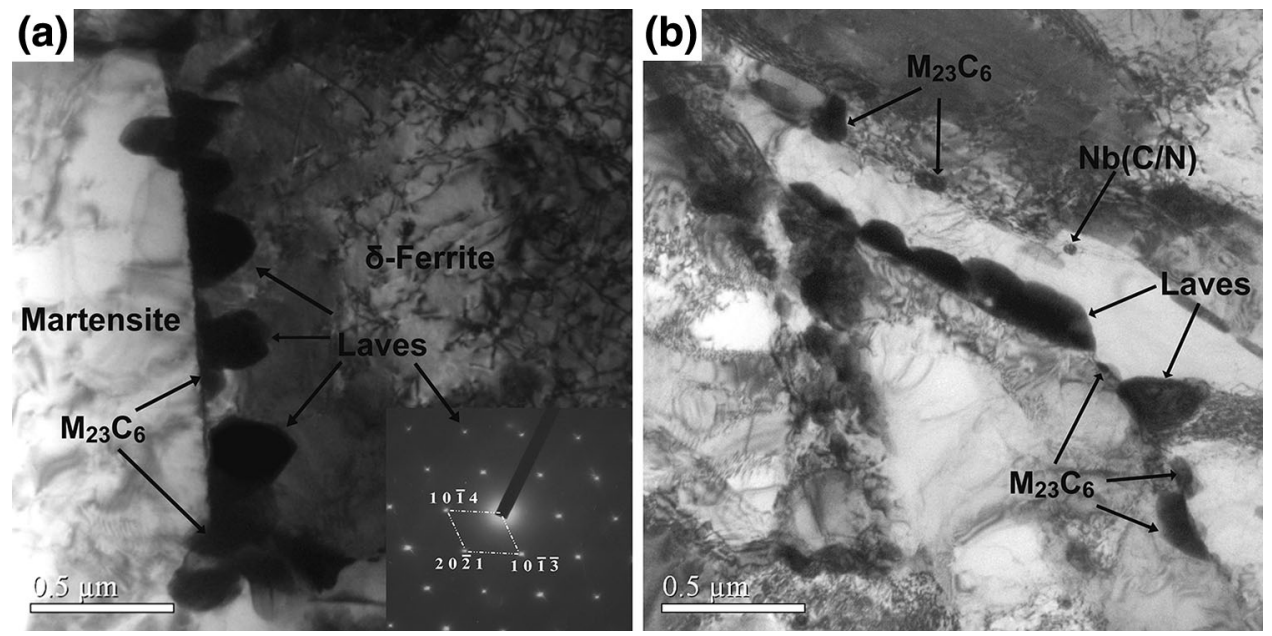

Fig. 8 TEM micrographs of No. 4 steel with diffraction patterns of Laves after heat treatment at $1,060{ }^{\circ} \mathrm{C} \times 20 \mathrm{~min} \mathrm{AC}+765{ }^{\circ} \mathrm{C} \times 3 \mathrm{~h} \mathrm{AC}$ followed by aging at $625^{\circ} \mathrm{C} \times 1,000 \mathrm{~h} \mathrm{AC}$

austenitization and are also found to be highly resistant to coarsening during tempering, which are beneficial for the microstructure stability of P92 [16, 18]. The microstructures of Nos. 2-4 steels after normalization and tempering are similar to those of No. 1 steel with a slightly denser $\mathrm{M}_{23} \mathrm{C}_{6}$ of larger dimension distributed on various boundaries, which may be resulted from the additional alloying elements.
After heat treatment at $1,060{ }^{\circ} \mathrm{C} \times 20 \mathrm{~min}$, $\mathrm{AC}+765^{\circ} \mathrm{C} \times 3 \mathrm{~h}, \mathrm{AC}$, aging heat treatment at $625^{\circ} \mathrm{C}$ for $1,000 \mathrm{~h}, \mathrm{AC}$ is carried out to investigate the microstructure evolution and is prepared for stress-rupture tests. As revealed in the TEM micrographs of No. 4 steel in Fig. $8, \mathrm{M}_{23} \mathrm{C}_{6}$ carbides grew significantly during aging heat treatment, while the MX carbonitrides exhibited slightly coarsening tendency. What's more, the Laves phase can 
Table 3 Variations of the stress-rupture life, elongation $(\varepsilon)$ and reduction in area $(\psi)$ with the test carried out first at $625^{\circ} \mathrm{C} / 125 \mathrm{MPa}$ for $2,900 \mathrm{~h}$ and then at $625^{\circ} \mathrm{C} / 140 \mathrm{MPa}$ to rupture (The stress-rupture life is the total time consumed by both parts of test)

\begin{tabular}{llll}
\hline Steel & Stress-Rupture life (h) & $\varepsilon(\%)$ & $\psi(\%)$ \\
\hline No. 1 & 3,742 & 24 & 82 \\
No. 2 & 4,523 & 24 & 83 \\
No. 3 & 4,285 & 23 & 83 \\
No. 4 & 2,021 & 22 & 80 \\
\hline
\end{tabular}

also be identified at the prior austenite grain boundaries and $\delta$-ferrite/martensite interface. Similar microstructures were observed in Nos. 1-3 steels. Laves phase distributed at the interface of $\delta$-ferrite and martensite matrix with dimension larger than $300 \mathrm{~nm}$ may impair the stress-rupture properties by consuming too much both $\mathrm{W}$ and Mo and failing to inhibit grain boundary sliding and/or dislocation moving effectively [27]. In addition, the Laves phase has the tendency to precipitate at the area near $\mathrm{M}_{23} \mathrm{C}_{6}$ carbides with the carbides dissolving into the Laves phase and martensite matrix, thus weakening the precipitation strengthening endowed by fine-distributed $\mathrm{M}_{23} \mathrm{C}_{6}$ carbides [18].

The stress-rupture test after aging heat treatment is carried out first at $625{ }^{\circ} \mathrm{C} / 125 \mathrm{MPa}$ for $2,900 \mathrm{~h}$ and at $625^{\circ} \mathrm{C} / 140 \mathrm{MPa}$ afterward. The variations of stress-rupture life, elongation $(\varepsilon)$ and reduction in area $(\psi)$ are shown in Table 3. The stress-rupture life increased significantly from about 3,742 h of No. 1 steel to about 4,285 h of No. 3 steel, which indicates that $\mathrm{Ce}$ element has a beneficial effect on stress-rupture life of P92 steel. The No. 2 steel with a small amount of both $\mathrm{Cr}$ and $\mathrm{W}$ exhibits the highest stress-rupture life of 4,523 $\mathrm{h}$ among all the samples after twice loading. However, the stress-rupture life of No. 4 steel dramatically decreased to about 2,021 h, which indicates that $\mathrm{Si}$ element can obviously impair the stress-rupture life of P92 steel. On the other hand, the high
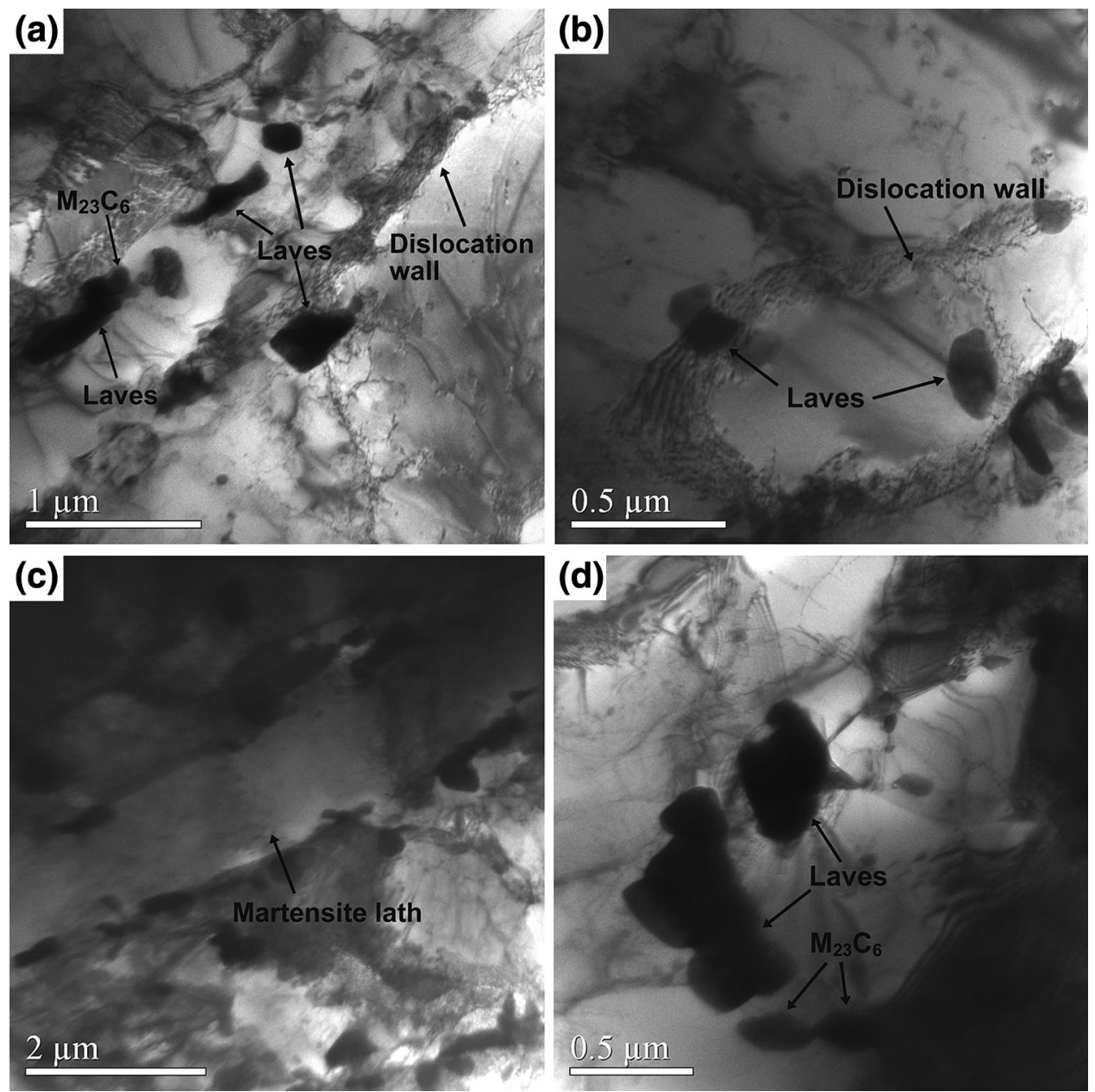

Fig. 9 TEM micrographs of No. 1 a, No. 2 b, No. 3 c, No. 4 d steels after stress-rupture tests carried out first at $625{ }^{\circ} \mathrm{C} / 125 \mathrm{MPa}$ for $2,900 \mathrm{~h}$ and at $625{ }^{\circ} \mathrm{C} / 140 \mathrm{MPa}$ afterward 
temperature elongation $(\varepsilon)$ and reduction in area $(\psi)$ of all the steels varied slightly.

The TEM micrographs after stress-rupture tests are shown in Fig. 9. The Laves phases and $\mathrm{M}_{23} \mathrm{C}_{6}$ carbides grew significantly, and the dimension of some particles is larger than $400 \mathrm{~nm}$ as shown in No. 1 steel (Fig. 9a). It is generally accepted that homogeneously distributed and fine-dimensional $\mathrm{M}_{23} \mathrm{C}_{6}$ carbides and Laves phase rich in $\mathrm{Cr}$ and $\mathrm{W}$ favor the creep strength in terms of the so called dispersion strengthening and precipitation strengthening [21]. So the stress-rupture life of No. 2 steel with additional both $\mathrm{Cr}$ and $\mathrm{W}$ was significantly improved by forming more particles to inhabit, say, dislocation moving as shown in the Fig. 9b. Hu et al. [20] also reported that after adding proper $\mathrm{Cr}, \mathrm{W}$, and $\mathrm{Co}$, the rupture life of $\mathrm{P} 92$ remarkably increased from $431 \mathrm{~h}$ to about $8,354 \mathrm{~h}$ with creep test at $600{ }^{\circ} \mathrm{C} / 210 \mathrm{MPa}$, which is in good line with the beneficial effect of $\mathrm{Cr} / \mathrm{W}$ on the rupture strength in the present work. Figure $9 \mathrm{c}$ shows that the martensite lath was still well maintained in No. 3 steel after long-term stress-rupture test. $\mathrm{Ce}$ tends to segregate strongly at the grain boundaries enhancing atomic bond strength, which results in improving grain boundary cohesion and reducing the tendency to brittle intergranular fracture [28]. Besides, minor additions of $\mathrm{Ce}$ are found to be highly effective in removing impurity elements such as $\mathrm{O}$ and $\mathrm{S}$ in austenitic stainless steel through the formation of $\mathrm{Ce}_{2} \mathrm{O}_{2} \mathrm{~S}$ that reduces the creep cavity and finally increases the creep strength $[29,30]$. Si dramatically promotes the formation of the precipitates $[31,32]$, and the dimension of Laves phase further increases to more than $500 \mathrm{~nm}$ after stress-rupture test in No. 4 steel. The Laves phase in large size impairs the stress-rupture properties of the steel and fails to effectively inhabit the movement of grain boundary and dislocations [21]. Furthermore, as the precipitates grow beyond a certain size, the coherency between the precipitates and matrix disappears, and their interfaces serve as favorable nucleation and growth sites of micro-cavities, which influence creep deformation, and therefore, the rupture time of a specimen [27]. So the stress-rupture life of No. 4 steel dramatically decreased to $2,021 \mathrm{~h}$. Although in any case the optimization of the silicon content is not so easy, combined with the pronouncedly improved oxidation resistance of No. 4 steel as discussed above, it is believed that it will be possible to keep a good balance between the oxidation resistance and stress-rupture property with the introduce of proper silicon.

\section{Conclusions}

Effects of alloy elements $\mathrm{Cr}, \mathrm{W}, \mathrm{Ce}$, and $\mathrm{Si}$ on oxidation resistance, stress-rupture property and microstructure evolution of $\mathrm{P} 92$ heat resistant steel have been investigated. All the modified samples showed improved oxidation resistance to different extent after oxidation at $750{ }^{\circ} \mathrm{C}$ for $700 \mathrm{~h}$ in air. The base sample and modified steel of additional $\mathrm{Cr}, \mathrm{W}$, or $\mathrm{Ce}$ yielded almost the same oxidation products with the constituents of the innermost $\mathrm{Cr}_{2} \mathrm{O}_{3} /(\mathrm{Fe}$, $\mathrm{Cr}_{3} \mathrm{O}_{4}$-mixed layer, the intermediate $\mathrm{Fe} / \mathrm{Cr}$-rich $(\mathrm{Fe}$, $\mathrm{Cr})_{3} \mathrm{O}_{4}$, and the outermost Fe-rich mixture of $\alpha-\mathrm{Fe}_{2} \mathrm{O}_{3}$ and $\mathrm{Fe}_{3} \mathrm{O}_{4}$. Modified P92 with addition of $\mathrm{Ce} / \mathrm{Si}$ exhibits the best oxidation resistance but possesses the worst creep strength at the same time due to the formation and coarsening of Laves phase with large size. Both the oxidation resistance and stress-rupture life were obviously enhanced for modified P92 with addition of Ce. Modified P92 with addition of $\mathrm{Cr} / \mathrm{W}$ achieved the highest rupture life $(4,523 \mathrm{~h})$ at $625{ }^{\circ} \mathrm{C} /(120+140) \mathrm{MPa}$ and the improved oxidation at $750{ }^{\circ} \mathrm{C}$ in air, which makes it the optimum steel in the present work. The combination of enhanced oxidation resistance and improved stress-rupture strength of the samples with additional $\mathrm{Cr}, \mathrm{W}$, and $\mathrm{Ce}$ indicates that proper additions of these alloying elements have beneficial effect on the comprehensive properties of P92 steel.

Acknowledgments The authors would like to thank J.C. Peng and P.F Hu for the excellent support during JEM 2010F TEM observations, B. Lu for Raman analysis and Y.L. Chu for SEM analysis in Instrumental Analysis \& Research Center of Shanghai University.

\section{References}

[1]. F. Yin, W. Jung, S. Chung, Scripta Mater. 57, 469 (2007)

[2]. X.Q. Hu, N.M. Xiao, X.H. Luo, D.Z. Li, J. Mater. Sci. Technol. 26, 817 (2010)

[3]. L. Tan, X. Ren, T.R. Allen, Corros. Sci. 52, 1520 (2010)

[4]. D. Laverde, T. Gómez-Acebo, F. Castro, Corros. Sci. 46, 613 (2004)

[5]. N.Q. Zhang, H. Xu, B.R. Li, Y. Bai, D.Y. Liu, Corros. Sci. 56, $123(2012)$

[6]. A.S. Khanna, P. Rodriguez, J.B. Gnanamoorthy, Oxid. Met. 26, 171 (1986)

[7]. I.G. Wright, B.A. Pint, Proceeding of NACE Corrosion 2002, Denver, CO, No. 02377 (2002)

[8]. H.E. Evans, D.A. Hilton, R.A. Holm, S.J. Webster, Oxid. Met. 19, 1 (1983)

[9]. Y. Suzuki, T. Yamashita, Y. Sugimoto, S. Fujita, S. Yamaguchi, ISIJ Int. 49, 564 (2009)

[10]. T. Sundararajan, S. Kuroda, J. Kawakita, S. Seal, Surf. Coat. Technol. 201, 2124 (2006)

[11]. M. Schütze, M. Schorr, D.P. Renusch, A. Donchev, J.P.T. Vossen, J. Mater. Res. 7, 111 (2004)

[12]. V. Lepingle, G. Louis, D. Allué, B. Lefebvre, B. Vandenberghe, Corros. Sci. 50, 1011 (2008)

[13]. K.J. Yin, S.Y. Qiu, R. Tang, Q. Zhang, L.F. Zhang, J. Supercrit. Fluid. 50, 235 (2009)

[14]. X.F. Wang, W.Q. Chen, J. Rare. Earths 28, 295 (2010)

[15]. N. Dudova, A. Plotnikova, D. Molodov, A. Belyakov, R. Kaibyshev, Mater. Sci. Eng. A 534, 632 (2012) 
[16]. C.G. Panait, A. Zielińska-Lipiec, T. Koziel, A. Czyrska-Filemonowicz, A.F. Gourgues-Lorenzon, W. Bendick, Mater. Sci. Eng. A 527, 4062 (2010)

[17]. S.S. Wang, D.L. Peng, L. Chang, X.D. Hui, Mater. Des. 50, 174 (2013)

[18]. P.J. Ennis, A. Zielinska-Lipiec, O. Wachter, A. Czyrska-Filemonowicz, Acta Mater. 45, 4901 (1997)

[19]. R. Ma, Y.F. Yang, Q.Z. Yan, Y. Yang, X.G. Li, Acta Metall. Sin. (Engl. Lett.) 23, 451 (2010)

[20]. P. Hu, W. Yan, W. Sha, W. Wang, Y.Y. Shan, K. Yang, J. Mater. Sci. Technol. 27, 344 (2011)

[21]. C.S. Jeong, S.Y. Bae, D.H. Ki, K. Watanabe, B.S. Lim, Mater. Sci. Eng. A 449-451, 155 (2007)

[22]. Q.M. Jin, J. Li, Y.L. Xu, X.S. Xiao, Corros. Sci. 52, 2846 (2010)

[23]. Y.L. Xu, Q.M. Jin, J. Li, X.S. Xiao, X. Zhang, L.Z. Jiang, Corros. Sci. 52, 2846 (2010)

[24]. F.H. Yu, G.H. Yang, R.D. Han, H.M. Weng, Acta Metall. Sin. 28, 49 (1992). (in Chinese)
[25]. A.M. Huntz, V. Bague, G. Beauplé, C. Haut, C. Sévérac, P. Lecour, X. Longaygue, F. Ropital, Appl. Surf. Sci. 207, 255 (2003)

[26]. G.H. Meier, K. Jung, N. Mu, N.M. Yanar, F.S. Pettit, J.P. Abellán, T. Olszewski, L.N. Hierro, W.J. Quadakkers, G.R. Holcomb, Oxid. Met. 74, 319 (2010)

[27]. A. Kipelova, R. Kaibyshev, A. Belyakov, D. Molodov, Mater. Sci. Eng. A 528, 1280 (2011)

[28]. Z.X. Yuan, S.H. Song, T.H. Xi, X.J. Zhang, Z.S. Yu, Acta Metall. Sin. (Engl. Lett.) 10, 349 (1997)

[29]. K. Laha, J. Kyono, T. Sasaki, S. Kishimoto, N. Shinya, Metall. Mater. Trans. A 36, 399 (2005)

[30]. Y.L. Xu, H. Nie, J. Li, X.S. Xiao, Mater. Sci. Eng. A 528, 643 (2010)

[31]. M.J. Cieslak, T.J. Headley, T. Kollie, A.D. Romig, Metall. Trans. A 19, 2319 (1988)

[32]. J.T. Guo, C. Shi, Acta Metall. Sin. 14, 348 (1978). (in Chinese) 